\title{
ANALISIS DAMPAK PEMBANGUNAN SMELTER NIKEL TERHADAP PEREKONOMIAN DAERAH DI PROVINSI SULAWESI TENGGARA
}

\section{ANALYSIS THE IMPACT OF THE NICKEL SMELTER DEVELOPMENT TOWARD THE REGIONAL ECONOMY IN THE SOUTHEAST SULAWESI PROVINCE}

\author{
Harta Haryadi \\ Pusat Penelitian dan Pengembangan Teknologi Mineral dan Batubara \\ Jalan Jenderal Sudirman No. 623 Bandung 40211 \\ Telp. (022) 6030483, Fax. (022) 6003373 \\ hartah@tekmira.esdm.go.id
}

\section{ABSTRAK}

Penelitian ini bertujuan untuk mengetahui dampak pembangunan smelter nikel di Provinsi Sulawesi Tenggara terhadap perekonomian, dengan menghitung Produk Domestik Regional Bruto (PDRB) menggunakan tiga pendekatan:pendekatan produksi $Y=[(\mathrm{Q} 1 \mathrm{X} \mathrm{P} 1)+(\mathrm{Q} 2 \mathrm{X}$ $\mathrm{P} 2)+(\mathrm{Qn} X \mathrm{Pn}) \ldots . .$.$] , pendekatan pengeluaran \mathrm{Y}=\mathrm{C}+\mathrm{I}+\mathrm{G}+(\mathrm{X}-\mathrm{M})$, dan pendekatan pendapatan $Y=R+W+I+P$.

Metodologi yang digunakan terdiri dari survei langsung terhadap beberapa perusahaan tambang nikel yang dijadikan studi kasus dan ditambah dengan studi pustaka untuk memperkaya hasil penelitian.

Hasil penelitian menunjukkan bahwa rencana pembangunan smelter nikel ini memberikan dampak yang positif bagi perekonomian Provinsi Sulawesi Tenggara yang meningkat sebesar Rp. 85,22 triliun, serta memberikan kesempatan lapangan kerja baru sebanyak 8.100 orang yang secara tidak langsung akan meningkatkan kemampuan daya beli masyarakat.

Kata kunci: Dampak perekonomian, produk domestik regional bruto, smelter nikel, sulawesi tenggara.

\section{ABSTRACT}

This paper aims to understand the impact smelter development for nickel mineral in the Southeast Sulawesi Province to the economy by calculating Gross Regional Domestic Product $(G R D P)$ using 3 approaches, i.e. production $Y=[(Q 1 X P 1)+(Q 2 X P 2)+(Q n X P n)$ ...... s, spending $Y=C+I+G+(X-M)$, and yield $Y=R+W+I+P$.

Methodology consists of direct survey to several companies of Nickel Mine as cases study as well as literature study to enrich the result.

The results show that the planning to develop nickel smelter will give positive impact for the economy of Southeast Sulawesi Province as much as Rp. 85.22 trillion, and will give the new employment for 8,100 people, which indirectly will increase the purchasing power of communities.

Keywords: Impact of economy, gross regional domestic product, nickel smelter, Southeast Sulawesi. 


\section{PENDAHULUAN}

Wilayah Provinsi Sulawesi Tenggara seluas $148.140 \mathrm{~km}^{2}$, terdiri dari $74,25 \%$ $\left(110.000 \mathrm{~km}^{2}\right)$ perairan laut dan $25,75 \%$ $\left(38.140 \mathrm{~km}^{2}\right)$ daratan. Provinsi Sulawesi Tenggara terdiri dari 10 wilayah kabupaten, yaitu Kabupaten Buton, Kabupaten Muna, Kabupaten Konawe, Kabupaten Kolaka, Kabupaten Konawe Selatan, Kabupaten Wakatobi, Kabupaten Bombana, Kabupaten Kolaka Utara, Kabupaten Buton Utara, Kabupaten Konawe Utara dan dua wilayah kota, yaitu Kota Kendari dan Kota Bau-Bau (Anonim, 2013).

Dalam Masterplan Percepatan dan Perluasan Pembangunan Ekonomi Indonesia (MP3EI), Sulawesi Tenggara termasuk ke dalam Koridor Sulawesi dengan tema "Pusat Produksi dan Pengolahan Hasil Pertanian, Perkebunan, dan Perikanan serta Pertambangan Nikel Nasional". Tema pembangunan koridor ekonomi tersebut sejalan dengan potensi kekayaan yang ada di Provinsi Sulawesi Tenggara. Oleh karena itu, Provinsi Sulawesi Tenggara ideal untuk dijadikan Kawasan Ekonomi Khusus yang sedang digalakkan oleh Pemerintah (Anonim, 2011).

Keberadaan sumber daya nikel diwilayah Provinsi Sulawesi Tenggara sangat besar (Tabel 1 dan Gambar 1), namun belum memberikan manfaat yang signifikan bagi perekonomian wilayah tersebut. Hal ini disebabkan masih kurangnya kegiatan eksplorasi yang dilakukan, sehingga sumber daya tersebut belum bisa menjadi cadangan yang siap tambang, disamping itu nikel yang sudah diproduksi selanjutnya diekspor dalam bentuk mentah (Anonim, 2015a).

Sumber daya yang besar di Provinsi Sulawesi Tenggara sangat penting untuk dijadikan modal dasar bagi pembangunan wilayah serta untuk memberdayakan potensi tersebut menjadi kekuatan ekonomi yang riil, juga sebagai daya dukung bagi keberlangsungan pemasokan bahan baku bagi pabrik pengolahan dan pemurnian nikel di wilayah tersebut. Berdasarkan data dari Dinas Pertambangan dan Energi Provinsi Sulawesi Tenggara wilayah ini memiliki sumber daya mineral nikel dalam jumlah yang cukup besar dan terbesar di Indonesia, dengan total sumber daya mencapai 97.401.593.026 ton (Anonim, 2015b). Sumber daya nikel yang besar ini diharapkan dapat mendukung rencana pembangunan 20 pabrik pengolahan dan pemurnian nikel di Provinsi Sulawesi Tenggara hingga lebih dari 100 tahun, dengan tingkat kebutuhan rata-rata bahan baku untuk seluruh pabrik pengolahan dan pemurnian nikel sebesar 12.494 .722 ton setiap tahunnya.

Hasil dari penelitian ini diharapkan dapat mendukung terealisasinya pabrik pengolahan dan pemurnian nikel di Provinsi Sulawesi Tenggara, sebagai amanat dari UU No. 4 Tahun 2009 tentang Pertambangan Mineral dan Batubara, dan Peraturan Menteri (Permen) ESDM No.8 Tahun 2015 Tentang Peningkatan Nilai Tambah Mineral Melalui Kegiatan Pengolahan dan Pemurnian Mineral di Dalam Negeri. Permen ini mewajibkan komoditi nikel diolah sebelum diekspor dan melarang perusahaan tambang menjual produknya dalam bentuk bijih dan konsentrat mulai tahun 2017. 


\section{MAKALAH ILMIAH}

Tabel 1. Potensi Sumber Daya Nikel di Provinsi Sulawesi Tenggara.

\begin{tabular}{|c|c|c|c|c|c|}
\hline No & Kabupaten & Sumber Daya(Ton) & $\begin{array}{l}\text { Total ProduksiPeriode } \\
2008-2013\end{array}$ & $\begin{array}{c}\text { Sumber } \\
\text { DayaTersisa (Ton) }\end{array}$ & $\begin{array}{c}\text { Kadar Hasil Uji } \\
\text { Laboratorium Sampel } \\
\text { Bahan Galian }\end{array}$ \\
\hline 1 & Konawe Utara & 46.007 .440 .652 & 16.249 .021 & 45.991 .191 .631 & $\begin{array}{l}\text { Ni } 1,91-2,4 \% ; \mathrm{Fe} \\
14,07-17,47 \%\end{array}$ \\
\hline 2 & Bombana & 28.200 .014 .800 & 5.335 .801 & 28.194 .678 .999 & \\
\hline No & Kabupaten & Sumber Daya(Ton) & $\begin{array}{l}\text { Total ProduksiPeriode } \\
2008-2013\end{array}$ & $\begin{array}{l}\text { Sumber DayaTersisa } \\
\text { (Ton) }\end{array}$ & $\begin{array}{c}\text { Kadar Hasil Uji } \\
\text { Laboratorium Sampel } \\
\text { Bahan Galian }\end{array}$ \\
\hline 3 & Kolaka & 12.819 .244 .028 & 16.071 .935 & 12.803.172.092 & Ni $2,17 \% ;$ Fe $34 \%$ \\
\hline 4 & $\begin{array}{l}\text { Konawe } \\
\text { Selatan }\end{array}$ & 4.348 .838 .160 & 8.007 .223 & 4.340 .830 .937 & $\begin{array}{l}\text { Ni } 2,11-2,13 \% ; \mathrm{Fe} \\
21,96-23,03 \%\end{array}$ \\
\hline 5 & Kolaka Utara & 2.763 .796 .196 & 6.654 .418 & 2.757 .141 .777 & $\begin{array}{l}\mathrm{Ni} 1,76-1,9 \% ; \mathrm{Fe} 18,1- \\
20,18 \%\end{array}$ \\
\hline 6 & $\begin{array}{l}\text { Buton dan Kota } \\
\text { Bau-Bau }\end{array}$ & 1.676 .332 .000 & 2.035 .966 & 1.674 .296 .034 & $\begin{array}{l}\text { Ni 2-2,07\%; Fe 20,10- } \\
34 \%\end{array}$ \\
\hline 7 & Konawe & 1.585 .927 .189 & 40.000 & 1.585 .887 .189 & $\begin{array}{l}\mathrm{Ni} 1,8-2 \% ; \mathrm{Fe} 18,03- \\
16,25 \%\end{array}$ \\
\hline 8 & $\begin{array}{l}\text { Lintas } \\
\text { Kabupaten }\end{array}$ & & 2.568 .344 & & \\
\hline & Jumlah & 97.401 .593 .025 & 56.962 .709 & 97.344 .630 .316 & \\
\hline
\end{tabular}

Sumber: Dinas Pertambangan ESDM Provinsi Sulawesi Tenggara, 2015

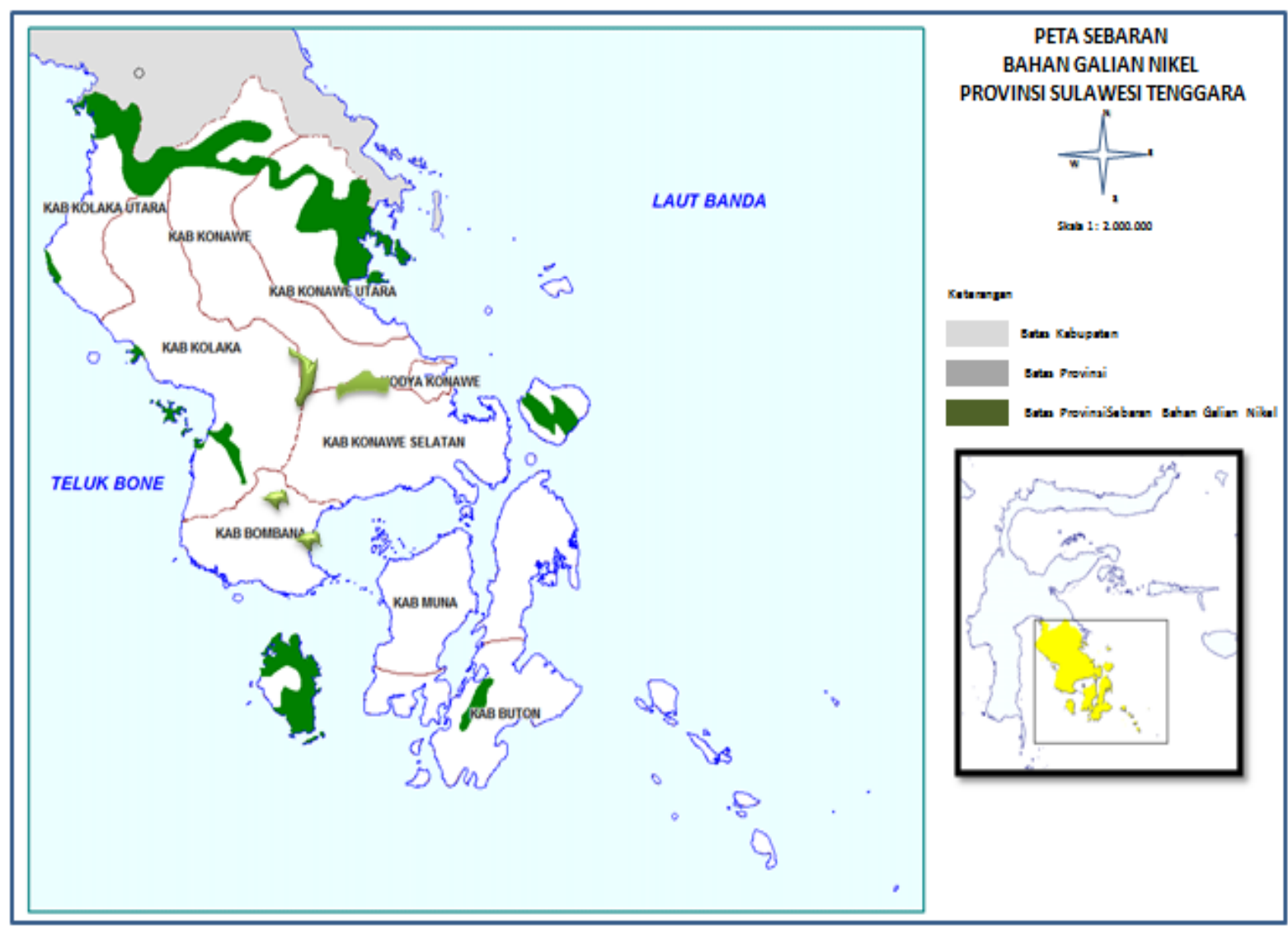

Sumber : Dinas Pertambangan dan Energi Provinsi Sulawesi Tenggara, 2015

Gambar 1. Peta Sebaran Nikel di Provinsi Sulawesi Tenggara. 


\section{MAKALAH ILMIAH}

\section{Rencana Pabrik Pengolahan Pemurnian Nikel}

Tambang nikel merupakan andalan utama Provinsi Sulawesi Tenggara, yang mampu meningkatkan perekonomian daerah. Berdasarkan data dari Direktorat Jenderal Minerba tahun 2015 ada 20 perusahaan besar (Tabel 2).

Terbitnya UU Nomor 4 Tahun 2009 tentang Pertambangan Mineral dan Batubara, yang mewajibkan proses pengolahan dan pemurnian bagi berbagai jenis mineral termasuk mengolah nikel menjadi Nickel Pig Iron (NPI), Nickel Matte (Sponge Nickel) dan Ferro Nickel sebelum diekspor, di satu sisi akan meningkatkan perekonomian dan Pendapatan Asli Daerah, serta membuka peluang bagi peningkatan penyerapan tenaga kerja. Di sisi lain, diperlukan upaya pengadaan energi dalam rangka mengoperasikan pabrik pengolahan/pemurniannya dan perbaikan/pengadaan infrastruktur. Suatu tantangan yang harus dihadapi oleh Provinsi Sulawesi Tenggara agar nikel dapat dijadikan andalan. Keseluruhan rencana pembangunan pabrik pengolahan dan pemurnian nikel di Provinsi Sulawesi Tenggara dapat dilihat pada Tabel 2.

Di bidang energi, tidak terlalu banyak potensi yang dapat dikembangkan, sebab Provinsi Sulawesi Tenggara tidak memiliki sumber energi yang besar sebagaimana halnya batubara di Provinsi Kalimantan Selatan, Provinsi Kalimantan Timur dan Provinsi Sumatera Selatan (dari sektor pengadaan listrik dan gas hanya 0,03\% dari struktur PDRB Provinsi Sulawesi Tenggara tahun 2014). Pengolahan nikel menjadi Nickel Pig Iron (NPI), Nickel Mate (Sponge Nickel), Ferro Nickel memerlukan energi yang sangat besar, sehingga Provinsi Sulawesi Tenggara perlu membangun pembangkit listrik untuk mendukung pabrik pengolahan dan pemurnian nikel.

\section{Peningkatan Nilai Tambah Mineral}

Menurut Kementerian Perindustrian, 2015. Industri adalah kegiatan ekonomi yang mengolah bahan mentah, bahan baku, barang setengah jadi, dan/atau barang jadi menjadi barang dengan nilai yang lebih tinggi untuk penggunaannya, termasuk kegiatan rancang bangun dan perekayasaan industri. Peningkatan Nilai Tambah (PNT) di sub-sektor pertambangan diartikan secara luas berupa proses pengolahan hasil tambang dari bahan mentah (raw material) yang bertujuan untuk menghasilkan produk jadi, sehingga nilai ekonomi dan daya gunanya meningkat lebih tinggi. PNT ini akan memberikan dampak positif terhadap perokonomian dan sosial baik bagi daerah operasional tambang, maupun daerah non-operasional dalam satu wilayah provinsi, dan dampak positif terhadap pusat. 
Tabel 2. Rencana Investasi Pembangunan Pabrik Pengolahan dan Pemurnian Nikel di Provinsi Sulawesi Tenggara.

\begin{tabular}{|c|c|c|c|c|c|c|c|}
\hline \multirow[b]{2}{*}{ No } & \multirow[b]{2}{*}{$\begin{array}{c}\text { Nama } \\
\text { Perusahaan }\end{array}$} & Cadangan & Input & Output & \multirow[b]{2}{*}{$\begin{array}{c}\text { Jumlah } \\
\text { Karyawan } \\
\text { [Orang] }\end{array}$} & \multirow[b]{2}{*}{$\begin{array}{c}\text { Target } \\
\text { Penyelesaian } \\
\text { Proyek }\end{array}$} & \multirow[b]{2}{*}{ Investasi } \\
\hline & & $\begin{array}{c}\text { Ton } \\
\text { \& Kadar Ni }\end{array}$ & $\begin{array}{c}\text { Kapasitas } \\
\text { Ton/Tahun } \\
\& \\
\text { Kadar Ni }\end{array}$ & $\begin{array}{c}\text { Kapasitas } \\
\text { Ton/Tahun } \\
\text { Kadar Ni }\end{array}$ & & & \\
\hline 1 & $\begin{array}{l}\text { PT Wijaya Inti } \\
\text { Nusantara }\end{array}$ & $\begin{array}{r}31.000 .000 \\
1,5 \%\end{array}$ & $\begin{array}{r}2.000 .000 \\
1,6 \%\end{array}$ & $\begin{array}{r}21.500-80.000 \\
15 \%\end{array}$ & 1.000 & Awal 2017 & Rp. 32,78 Triliun \\
\hline 2 & $\begin{array}{l}\text { PT Bintang } \\
\text { Smelter } \\
\text { Indonesia }\end{array}$ & $\begin{array}{r}39.000 .000 \\
1,5 \%\end{array}$ & $\begin{array}{r}1.000 .000 \\
1,5 \%\end{array}$ & $\begin{array}{r}50.000--300.000 \\
9-11 \%\end{array}$ & 1.450 & $\begin{array}{l}\text { Des- } 2014 \\
\text { (Tahap 1) }\end{array}$ & Rp.1,43 Triliun \\
\hline 3 & $\begin{array}{l}\text { PT Cahaya } \\
\text { Modern Metal } \\
\text { Industri }\end{array}$ & $\begin{array}{r}40.000 .000 \\
1,8 \%\end{array}$ & $\begin{array}{r}850.000 \\
1,8 \%\end{array}$ & $\begin{array}{r}90.000 \\
10-12 \%\end{array}$ & 200 & Agust-14 & Rp. 500,00 Milyar \\
\hline 4 & $\begin{array}{l}\text { PT Elit kharisma } \\
\text { utama }\end{array}$ & $\begin{array}{r}70.000 .000 \\
1,1 \%\end{array}$ & $\begin{array}{r}850.000 \\
>1,8 \%\end{array}$ & $\begin{array}{r}90.000 \\
10-12 \%\end{array}$ & - & $\begin{array}{l}\text { Pertengahan } \\
2014\end{array}$ & Rp. 500,00 Milyar \\
\hline 5 & $\begin{array}{l}\text { PT Kembar } \\
\text { Emas Sultra }\end{array}$ & $\begin{array}{r}18.200 .000 \\
1,6-2,2 \%\end{array}$ & $\begin{array}{r}200.000 \\
1,4-1,8 \%\end{array}$ & $\begin{array}{l}35.000 \\
7-14 \%\end{array}$ & 500 & Maret 2014] & Rp. 213,75 Milyar \\
\hline 6 & PT Cinta Jaya & $\begin{array}{r}18.400 .000 \\
1,2-1,85 \%\end{array}$ & $\begin{array}{r}150.000 \\
>1,65 \& \text { Fe } 23-25\end{array}$ & $\begin{array}{r}16.200 \\
4-6 \%\end{array}$ & 270 & Apr-14 & Rp. 213,75 Milyar \\
\hline 7 & $\begin{array}{l}\text { PT Karyatama } \\
\text { Konawe Utara }\end{array}$ & $\begin{array}{r}80.000 .000 \\
1,6 \%\end{array}$ & $\begin{array}{r}550.000 \\
-\end{array}$ & $\begin{array}{r}50.000 \\
10 \%\end{array}$ & 500 & $\begin{array}{l}\text { Kuartal I } \\
2015\end{array}$ & Rp. 641,25 Milyar \\
\hline 8 & $\begin{array}{l}\text { PT BHINNEKA } \\
\text { SEKARSA } \\
\text { ADIDAYA }\end{array}$ & $\begin{array}{r}28.000 .000 \\
>1,7 \%\end{array}$ & $\begin{array}{r}1.000 .000 \\
>1,7 \%\end{array}$ & $\begin{array}{r}300.000 \\
8-12 \%\end{array}$ & 250 & Jul-15 & Rp. 2,15 Triliun \\
\hline 9 & $\begin{array}{l}\text { PT Bososi } \\
\text { Pratama }\end{array}$ & $\begin{array}{r}106.000 .000 \\
1,1-1,8 \%\end{array}$ & $1,1 \%-1,8 \%$ & $\begin{array}{l}52.000 \\
6-10 \%\end{array}$ & 200 & 2015 & Rp. 826,50 Milyar \\
\hline 10 & $\begin{array}{l}\text { PT Cipta Djaya } \\
\text { Surya }\end{array}$ & $\begin{array}{r}40.000 .000 \\
1,6-2,0 \%\end{array}$ & - & - & - & - & - \\
\hline 11 & $\begin{array}{l}\text { PT Dharma } \\
\text { Rosadi } \\
\text { Internasional }\end{array}$ & $\begin{array}{r}30.000 .000 \\
1,6 \%\end{array}$ & $\begin{array}{r}200.000-350.000 \\
1,2-1,8 \%\end{array}$ & $\begin{array}{r}20.000-40.000 \\
20-40 \%\end{array}$ & 400 & 2017 & Rp. 5,72 Triliun \\
\hline 12 & $\begin{array}{l}\text { PT Pulau Rusa } \\
\text { tamita }\end{array}$ & $\begin{array}{r}24.000 .000 \\
1,8 \%\end{array}$ & $\begin{array}{r}400.000 \\
1,8 \%\end{array}$ & $\begin{array}{r}10.000-20.000 \\
7-11 \%\end{array}$ & 1200 & 2016 & Rp. 715,00 Milyar \\
\hline 13 & $\begin{array}{l}\text { PT Tristaco } \\
\text { Mineral Makmur }\end{array}$ & $\begin{array}{r}12.000 .000 \\
1,8 \%\end{array}$ & $\begin{array}{r}240.000-240.000 \\
1,8 \%\end{array}$ & $\begin{array}{r}20.160 \\
10,1 \%\end{array}$ & 70 & akhir 2015 & Rp. 71,50 Milyar \\
\hline 14 & $\begin{array}{l}\text { PT Macika } \\
\text { Mineral Industri }\end{array}$ & $\begin{array}{r}17.000 .000 \\
1,83 \%\end{array}$ & $\begin{array}{r}503.426 \\
1,86 \%\end{array}$ & $\begin{array}{r}53.680 \\
10-12 \%\end{array}$ & - & 2017 & Rp. 597,07 Milyar \\
\hline 15 & $\begin{array}{l}\text { PT Putra } \\
\text { Mekongga } \\
\text { Sejahtera }\end{array}$ & $\begin{array}{r}15.000 .000 \\
>1,5 \%\end{array}$ & $\begin{array}{r}500.000 \\
1,5-1,6 \%\end{array}$ & $\begin{array}{r}75.000 \\
5 \%\end{array}$ & 350 & Apr-16 & Rp. 213,75 Milyar \\
\hline 16 & PT Jilin Metal & $\begin{array}{r}84.000 .000 \\
1,10 \%\end{array}$ & $\begin{array}{r}2.000 .000 \\
1,6 \%\end{array}$ & $\begin{array}{r}21.500-80.000 \\
15 \% \mathrm{FeNi}\end{array}$ & 1.000 & awal 2017 & Rp. 32,78 Triliun \\
\hline 17 & $\begin{array}{l}\text { PT Sambas } \\
\text { Mineral Mining }\end{array}$ & $\begin{array}{r}60.000 .000 \\
1,8 \%\end{array}$ & $\begin{array}{r}168.000 \\
1,8 \%\end{array}$ & $\begin{array}{l}132.000 \\
10-12 \%\end{array}$ & 150 & Sep-14 & Rp.142,50 Milyar \\
\hline 18 & $\begin{array}{l}\text { PT Stargate } \\
\text { Pacific } \\
\text { Resources }\end{array}$ & $\begin{array}{r}104.000 .000 \\
1,2 \%\end{array}$ & $\begin{array}{r}400.000 \\
1,8 \%\end{array}$ & $\begin{array}{r}200.000 \\
12 \% \mathrm{FeNi}\end{array}$ & 400 & 2016 & Rp. 4,29 Triliun \\
\hline 19 & PTIfishdeco & $\begin{array}{r}40.000 .000 \\
1,9 \%\end{array}$ & $\begin{array}{r}1.000 .000 \\
1,9 \% \text { \& Fe } 23-24 \%\end{array}$ & $\begin{array}{r}100.000 \\
9-11 \%\end{array}$ & 1.000 & Des- 2015 & Rp. 1,43 Triliun \\
\hline 20 & $\begin{array}{l}\text { PT Surya Saga } \\
\text { Utama }\end{array}$ & $\begin{array}{r}17.000 .000 \\
1,5 \% \text { \& Fe } 22 \%\end{array}$ & $\begin{array}{r}60.480 \\
1,5 \% \text { \& Fe } 22 \%\end{array}$ & $\begin{array}{r}10.800 \\
>6 \%\end{array}$ & 164 & akhir 2015 & Rp. 85,00 Milyar \\
\hline & TOTAL & & 12.494 .722 & & 8.104 & & Rp. 85,22 Triliun \\
\hline
\end{tabular}

Sumber: Direktorat Jenderal Minerba, 2015 \& Dinas Pertambangan ESDM Provinsi Sulawesi Tenggara, 2015 
Adapun bahan baku industri (Kementerian Perindustrian, 2013), adalah bahan mentah yang diolah atau tidak diolah yang dapat dimanfaatkan sebagai sarana produksi dalam industri, misalnya nickel pig iron (NPI) hasil pengolahan dari bijih nikel kemudian dilakukan proses pengolahan selanjutnya menjadi ferro nickel. Dan barang setengah jadi adalah bahan mentah atau bahan baku yang telah mengalami satu atau beberapa tahap proses industri yang dapat diproses lebih lanjut menjadi barang jadi, misalnya ferro nickel untuk nickel mate (sponge nickel). Dari bahan baku industri ini apabila dilakukan pengolahan maka akan menjadi barang jadi. (Kementerian Perdagangan, 2013), barang jadi adalah barang hasil industri yang sudah siap pakai untuk konsumsi akhir ataupun siap pakai sebagai alat produksi, misalnya barang jadi logam nikel yang digunakan untuk industri konstruksi, industri mesin, industri peralatan listrik, industri mesin pengolahan makanan, industri pelat dan tabung, industri kimia, industri generator dimana seluruh industri-industri tersebut berbahan baku logam nikel.

Rancang bangun industri adalah kegiatan industri yang berhubungan dengan perencanaan pendirian industri/pabrik secara keseluruhan atau bagianbagiannya, sedangkan perekayasaan industri adalah kegiatan industri yang berhubungan dengan perancangan dan pembuatan mesin/peralatan pabrik dan peralatan industri lainnya

Sehubungan dengan hal tersebut, maka pada setiap kegiatan pengusahaan pertambangan mineral dan batubara diwajibkan meningkatkan nilai tambah, sesuai amanah dalam UU No. 4 Tahun 2009 tentang Pertambangan Mineral dan Batubara dalam Pasal 102 dinyatakan bahwa "Pemegang IUP dan IUPK wajib meningkatkan nilai tambah sumber daya mineral dan/atau batubara dalam pelaksanaan penambangan, pengolahan dan pemurnian, serta pemanfaatan mineral dan batubara". Proses pengolahan tersebut di atas ditetapkan berdasarkan Pasal 103 (1) yang menyatakan bahwa "Pemegang IUP dan IUPK Operasi Produksi wajib melakukan pengolahan dan pemurnian hasil penambangan di dalam negeri".

Pemberlakuan ketentuan mengenai PNT akan memberikan dampak negatif bagi wilayah tersebut antara lain:

- Kehilangan pendapatan sementara dari sektor pertambangan karena berhentinya kegiatan tambang, hingga pabrik pengolahan selesai dan produksi dimulai [comisioning].

- Terjadi pemutusan hubungan kerja (PHK) sementara hingga pabrik pengolahan selesai, sehingga terdapat angka pengangguran terhadap TK langsung dan tidak langsung untuk sementara.

- Laju pertumbuhan ekonomi bawah terhambat disebabkan CSR/ Comdev dari yang selama ini diperoleh dari perusahaan tambang untuk sementara berhenti.

- Untuk sementara terjadi keresahan sosial dari masyarakat yang selama ini hidup tergantung dari pekerjaan tambang.

- Terjadi ketidak sepahaman diantara birokrat, terutama di wilayah yang kaya akan sumber daya tambang, sebagaimana Provinsi Sulawesi Tenggara.

- Terganggunya pasar tambang dunia yang selama ini tergantung kepada bahan mentah Indonesia, yang sementara berimbas kepada pasar domestik.

Di sisi lain, dengan dibangunnya pabrik pengolahan dan pemurnian akan menimbulkan dampak positif, antara lain:

- Dapat meningkatkan perekonomian daerah berupa peningkatan Produk Domestik Regional Bruto (PDRB);

- Bertambahnya kesempatan untuk mendapatkan pekerjaan (meningkatnya tenaga kerja); 
- Adanya peningkatan pendapatan setiap rumah tangga yang dapat meningkatkan kemampuan daya beli masyarakat.

Pengertian Produk Domestik Bruto (PDB) menurut (Sugiarto dan Herlambang. $\mathrm{H}$, 2006), adalah jumlah nilai tambah barang dan jasa akhir yang dihasilkan oleh seluruh unit usaha ekonomi dalam suatu negara selama 1 tahun. Termasuk hasil produksi dan jasa yang dihasilkan perusahaan/orang asing yang berada di negara yang bersangkutan.Sedangkan pengertian Produk Domestik Regional Bruto (PDRB) adalah jumlah nilai tambah barang dan jasa akhir yang dihasilkan oleh seluruh unit usaha ekonomi dalam wilayah/kabupaten/kota/provinsi selama 1 tahun. Termasuk hasil produksi dan jasa yang dihasilkan perusahaan/orang asing yang berada di wilayah/kabupaten/ kota/provinsi yang bersangkutan.

Menurut Tulus dan Simon(2004), PDRB, baik atas dasar harga berlaku maupun atas dasar harga konstan merupakan indikator penting untuk mengetahui kondisi ekonomi di suatu provinsi dalam suatu periode tertentu.

a) PDRB atas dasar harga berlaku menggambarkan nilai tambah barang dan jasa yang dihitung menggunakan harga yang berlaku pada setiap tahun untuk mengetahui pergeseran dan struktur ekonomi wilayah/kabupaten/ kota/provinsi/negara bersangkutan.

b) PDRB atas dasar harga konstan menggambarkan nilai tambah barang dan jasa yang dihitung menggunakan harga yang berlaku pada satu tahun tertentu sebagai tahun dasar untuk mengetahui pertumbuhan ekonomi dari tahun ke tahun wilayah/ kabupaten/kota/provinsi/negara bersangkutan.

Berdasarkan harga konstan tahun 2010, pada tahun 2012 PDRB Provinsi Sulawesi Tenggara tercatat sebesar Rp. 59,78 triliun dengan jumlah penduduk sebanyak 2.345.465 jiwa maka pendapatan perkapita sebesar Rp.
25.489.785. Di tahun 2013 pendapatan regional meningkat menjadi Rp. 64,27 triliun dengan jumlah penduduk sebanyak 2.369.713 jiwa dan pendapatan perkapita sebesar Rp. 26.817.472.

Pada tahun 2014 PDRB Provinsi Sulawesi Tenggara meningkat lagi menjadi 68,30 triliun dengan jumlah penduduk sebanyak 2.448.081 jiwa dengan pendapatan per kapita sebesar Rp. 27.898.883 (lihat Tabel 3). Selama 3 tahun terakhir (2012-2014), perkembangan ekonomi Sulawesi Tenggara menunjukkan peningkatan PDRB rata-rata sebesar $6,26 \%$ setiap tahunnya lebih tinggi dari pertumbuhan nasional yang mencapai $6,02 \%$. Subsektor pertambangan memberikan kontribusi paling tinggi kedua setelah sektor pertanian dan kehutanan(Anonim, 2015d).

PDRB berdasarkan harga berlaku menurut lapangan usaha pada tahun 2012 Provinsi Sulawesi Tenggara tercatat sebesar Rp. 64,69 triliun dengan jumlah penduduk sebanyak 2.345.465 jiwa maka pendapatan perkapita sebesar Rp. 27.582.584. Di tahun 2013 pendapatan regional meningkat menjadi Rp. 71,04 triliun dengan jumlah penduduk sebanyak 2.369.713 jiwa dan pendapatan perkapita sebesar Rp. 29.641.133. Pada tahun 2014 PDRB Provinsi Sulawesi Tenggara meningkat lagi menjadi 78,62 triliun dengan jumlah penduduk sebanyak 2.448.081 jiwa dengan pendapatan per kapita sebesar Rp. 32.115.109 (Tabel 4).

Berdasarkan Pusat Data dan Teknologi Informasi KESDM tahun 2015, Selama tiga tahun terakhir (2012-2014), perkembangan ekonomi Sulawesi Tenggara berdasarkan harga berlaku menunjukkan pertumbuhan ekonomi (PDRB) rata-rata sebesar $10,24 \%$ setiap tahunnya. Dari Tabel 5 dapat diketahui sektor pertambangan memberikan kontribusi paling tinggi kedua $(20,14 \%)$ setelah sektor pertanian dan kehutanan $(25,64 \%)$, sementara sektor penyumbang terkecil bagi pendapatan regional Provinsi 
Sulawesi Tenggara selama periode tersebut adalah sektor pengadaan listrik dan gas $(0,03 \%)$.

\section{METODOLOGI}

Penelitian ini dilakukan dengan dua metode, yaitu:

- Pengumpulan data melalui studi pustaka yang terkait dengan penelitian dan kunjungan ke beberapa perusahaan yang merencanakan membangun pabrik pengolahan nikel yang menjadi studi kasus.

- Pengolahan data dilakukan melalui metode berikut:
a. Analisis deskriptif terhadap data yang berhubungan dengan PNT nikel. dampak pembangunan smelter nikel terhadap perekonomian daerah untuk merancang kebijakan
b. Perhitungan PDRB berdasarkan pada rencana pembangunan pabrik pengolahan dan pemurnian nikel dengan tiga pendekatan, yaitu:

\section{Metode Nilai Produksi}

Untuk menghitung pendapatan regional dengan menjumlahkan seluruh nilai tambah barang dan jasa yang diproduksi/total output seluruh sektor ekonomi masyarakat dalam satu tahun. Untuk menghitung PDRB dengan pendekatan ini dapat dirumuskan :

$$
\begin{aligned}
& Y=\left[\left(\begin{array}{lll}
\mathrm{X} & \mathrm{P} 1
\end{array}\right)+(\mathrm{Q} 2 \mathrm{X} \mathrm{P} 2)+\right. \\
& \text { (Qn X Pn) ...] } \\
& Y=\text { Pendapatan Nasional } \\
& Q=\text { kuantitas, } P=\text { harga } \\
& \mathrm{n}=\text { tahun }
\end{aligned}
$$

Jumlah output masing-masing sektor merupakan jumlah output seluruh perekonomian. Ada kemungkinan output yang dihasilkan suatu sektor perekonomian berasal dari output sektor lain/bisa juga merupakan input bagi sektor ekonomi yang lain lagi. Untuk menghindari terjadi penghitungan ganda (double counting), maka dalam perhitungan PDB dengan metode nilai produksi, yang dijumlahkan adalah nilai tambah (value added) masing-masing sektor (Pujoalwanto, 2014).

\section{Metode Pengeluaran atau Konsumsi}

Untuk menghitung PDRB dengan metoda pengeluaran atau konsumsi yaitu dengan menjumlahkan seluruh pengeluaran yang dilakukan seluruh rumah tangga ekonomi/pelaku ekonomi dalam suatu provinsi selama satu tahun. Untuk menghitung PDRB dengan pendekatan ini dapat dirumuskan :

$$
\begin{array}{ll}
\mathbf{Y} & =\mathbf{C}+\mathbf{I}+\mathbf{G}+(\mathbf{X}-\mathbf{M}) \\
\mathbf{Y} & =\text { pendapatan nasional } \\
\mathbf{C} & =\text { konsumsi } \\
\mathbf{I} & =\text { investasi } \\
\mathbf{G} & =\text { pengeluaran pemerintah } \\
\mathbf{X} & =\text { ekspor } \\
\mathbf{M} & =\text { impor }
\end{array}
$$

- Pengeluaran RT Konsumen/ Masyarakat (Household Consumption $) / C=$ Pengeluaran rumah tangga dipakai untuk konsumsi akhir, baik barang dan jasa yang habis dalam tempo setahun atau kurang (durable goods) maupun barang yang dapat dipakai lebih dari setahun/barang tahan lama (nondurable goods) Untuk mencukupi kebutuhan rumah tangga seperti membeli beras/lauk pauk/bayar listrik dll.

- Pengeluaran RT Perusahaan (Investment Expenditure $) / l=$ Pembentukan Modal Tetap Domestik Bruto (PMTDB) merupakan pengeluaran sektor dunia usaha [perubahan stok, baik berupa barang jadi maupun barang setengah jadi]. Menurut (Ratya A, Michael R., 2009), ada dua macam pembentukan modal domestik:

a. Investasi untuk pembelian modal tetap (investasi gedung/mesin).
b. Investasi untuk pembelian persediaan (investasi bahan baku/bahan setengah jadi dan bahan jadi).


Dalam metoda penghitungan berdasarkan Pengeluaran $=$ Pengeluaran Perusahaan \& Pengeluaran Pemerintah disatukan dalam komponen pembentukan modal tetap domestik bruto [PMTDB] dan komponen perubahan stok.

- Pengeluaran RT Pemerintah (Government Consumption)/G = yang digunakan untuk membeli barang dan jasa akhir (government expenditure). Sedangkan pengeluaran-pengeluaran untuk tunjangan-tunjangan sosial tidak masuk dalam perhitungan konsumsi pemerintah. Untuk melayani kepentingan masyarakat, ada 2 macam:

a. Pengeluaran untuk konsumsi (perlengkapan dan peralatan kantor/bayar gaji pegawai).

b. Pengeluaran untuk investasi (bangung jembatan/irigasi/pembangkit listrik/jalan, dll).

- Ekspor Neto (Net Export)/selisih nilai ekspor dengan impor. Ekspor neto (X M) yang positif menunjukkan ekspor > impor. Perhitungan ekspor neto dilakukan bila perekonomian melakukan transaksi dengan perekonomian negara lain. Yang harus diperhitungkan dalam pendapatan nasional ini adalah adalah Ekspor Netonya (Amir M.S, 2004).

\section{Metode Pendapatan}

Untuk menghitung PDRB dengan metoda pendapatan yaitu dengan menjumlahkan dari seluruh pendapatan (sewa/rent, gaji/wage, bunga/interest, keuntungan/profit) yang diterima pemilik faktor produksi [pemilik tanah/gedung, tenaga kerja, pemilik modal/uang/aset, pengusaha] dalam suatu provinsi selama satu tahun.

$$
\begin{array}{ll}
\mathbf{Y} & =\mathbf{r}+\mathbf{w}+\mathbf{i}+\mathbf{p} \\
\mathbf{Y} & =\text { pendapatan nasionao } \\
\mathrm{r} & =\text { pendapatan rent } \\
\mathbf{W} & =\text { pendapatan wage } \\
\mathrm{i} & =\text { pendapatan interest } \\
\mathrm{p} & =\text { pendapatan profit }
\end{array}
$$

Dari ketiga metoda perhitungan pendapatan regional tersebut, maka dengan metoda pengeluaran yaitu: $\mathbf{Y}=\mathbf{C}$ + I + G + (X - M) dapat dihitung dampak adanya pembangunan pabrik pengolahan dan pemurnian nikel terhadap peningkatan PDRB daerah tersebut.

\section{HASIL DAN PEMBAHASAN}

\section{Dampak Terhadap Perekonomian/ Produk Regional Bruto}

Sebagaimana dapat dilihat pada Tabel 2, seluruh rencana pembangunan pabrik pengolahan dan pemurnian nikel yang berjumlah 20 perusahaan akan menanamkan modalnya dalam bentuk investasi sebesar USD.5.904.900.000 atau dengan kurs rupiah saat ini (Oktober 2014 sebesar Rp. 14.250 per 1 USD sama dengan Rp. 84.144.825.000.000,- ) dan Rp. 1.085.000.000.000. Sehingga total seluruh investasi dari seluruh pabrik pengolahan dan pemurnian di Provinsi Sulawesi Tenggara berjumlah Rp. 85,229.825.000.000 (Rp. 85,22 triliun), yang akan selesai pembangunan seluruh mulai tahun 2016 sampai tahun 2018. Sehingga rata-rata investasi selama tiga tahun adalah Rp. 28.409.941.666.000 per tahun (Rp. 28,41 triliun).

Keberadaan pabrik pengolahan dan pemurnian nikel di Provinsi Sulawesi Tenggara akan memberikan dampak positif yang besar bagi pengembangan wilayah tersebut dengan meningkatnya pendapatan regionalnya setelah berjalannya pabrik pengolahan dan pemurnian mulai tahun 2016 sebesar jumlah investasi yang ditanamkan oleh pabrik tersebut, yaitu sebesar $Y=C+I$ (Rp. 28.409.941.666.000/Rp. 28,41 triliun) $+\mathrm{G}+(\mathrm{X}-\mathrm{M})$. Ini berarti pada tahun 2016,

pendapatan nasional yang terdiri dari konsumsi ditambah pengeluaran pemerintah berupa pendapatan ekspor dikurangi pengeluaran impor akan mendapat tambahan investasi sebesar Rp. 28,41 triliun (Tabel 2). 
Sebagaimana diketahui, PDRB Provinsi Sulawesi Tenggara berdasarkan harga konstan tahun 2010, pada tahun 2012 tercatat sebesar Rp. 59,78 triliun dengan jumlah penduduk sebanyak 2.345.465 jiwa maka pendapatan perkapita sebesar Rp. 25.489.785. Di tahun 2013 PDRB meningkat menjadi Rp. 64,27 triliun dengan jumlah penduduk sebanyak 2.369.713 jiwa dan pendapatan perkapita sebesar Rp. 26.817.472. Pada tahun 2014 PDRB Provinsi Sulawesi Tenggara meningkat lagi menjadi 68,30 triliun dengan jumlah penduduk sebanyak 2.448.081 jiwa dengan pendapatan per kapita sebesar Rp. 27.898 .883 (Tabel 3)

Dengan adanya investasi dari pabrik pengolahan dan pemurnian selama tahun 2016-2018 rata-rata sebesar $\mathrm{Rp}$. 28.409.941.666.000 per tahun (Rp. 28,41 triliun).Maka PDRB Provinsi Sulawesi Tenggara pada tahun 2016 meningkat menjadi Rp. 68.298.724,30 juta + investasi pabrik (Rp. 28.409.941,66 juta) = Rp. 96.708.665,96 juta (Rp. 96,71 triliun). Tahun 2017 meningkat menjadi Rp. 96,71 triliun + Rp. 28,41 triliun = Rp. 125,12 triliun. Dan pada tahun 2018 setelah seluruh pabrik selesai meningkat menjadi Rp. 125,12 triliun + Rp. 28,41 triliun = Rp. 153,53 triliun (Tabel 3 dan 4, dan asumsi
Produk Domestik Bruto dihitung sampai 2017).

\section{Dampak Terhadap Tenaga Kerja (SDM)}

Kesempatan kerja berkaitan dengan peningkatan $\mathrm{PDRB}$, sehingga tingginya jumlah pekerja akan menyebabkan naiknya barang dan jasa yang dihasilkan dan menyebabkan PDRB wilayah tersebut juga meningkat. Selanjutnya peningkatan ini dapat digunakan untuk investasi yang berpotensi akan memperbesar kesempatan kerja. Dampak lain yang berkaitan dengan PDRB dan kesempatan kerja adalah tingkat produktivitas tenaga kerja wilayah tersebut. PDRB Provinsi Sulwesi Tenggara akan naik jika terjadi peningkatan angkatan kerja juga peningkatan produktivitas tenaga kerja di wilayah tersebut.

Hal sebaliknya, pengangguran kerja secara tidak langsung berkaitan juga dengan PDRB. Tingginya jumlah pengangguran di wilayah bersangkutan akan menyebabkan turunnya PDRB. Makin banyak pengangguran makin sedikit barang dan jasa yang dihasilkan, makin kecil PDRB wilayah tersebut, selanjutnya pendapatan untuk investasi juga menurun, dan akan memperkecil peluang kesempatan kerja.

Tabel 3.PDRB Atas Dasar Harga Konstan (Juta Rupiah) Menurut Lapangan Usaha Tahun Dasar 2010, 2012-2014.

\begin{tabular}{|c|c|c|c|c|c|}
\hline No & Lapangan Usaha & 2012 & 2013 & 2014 & LP \\
\hline 1 & $\begin{array}{l}\text { Pertanian, Kehutanan, } \\
\text { dan Perikanan }\end{array}$ & $14.625 .406,59$ & $15.508 .217,36$ & $16.921 .607,78$ & 9,11 \\
\hline 2 & $\begin{array}{l}\text { Pertambangan dan } \\
\text { Penggalian }\end{array}$ & $13.833 .548,85$ & $14.866 .536,76$ & 14.148.927,78 & $-4,83$ \\
\hline 3 & Industri Pengolahan & $3.669 .856,82$ & $3.824 .676,91$ & 4.120.653,04 & 7,74 \\
\hline 4 & Pengadaan Listrik, Gas & $27.241,53$ & $30.958,17$ & $34.240,72$ & 10,60 \\
\hline 5 & Pengadaan Air & $119.052,07$ & $130.165,84$ & $139.232,37$ & 6,97 \\
\hline 6 & Konstruksi & $6.849 .365,64$ & $7.441 .991,91$ & $8.380 .774,94$ & 12,61 \\
\hline 7 & $\begin{array}{l}\text { Perdagangan Besar dan } \\
\text { Eceran, dan Reparasi } \\
\text { Mobil dan Motor }\end{array}$ & $6.888 .012,93$ & $7.515 .269,82$ & $8.139 .100,97$ & 8,30 \\
\hline 8 & $\begin{array}{l}\text { Transportasi dan } \\
\text { Pergudangan }\end{array}$ & 2.635.367,94 & $2.805 .301,60$ & $2.949 .138,28$ & 5,13 \\
\hline 9 & Penyediaan Akomodasi & $330.957,84$ & $358.542,18$ & $392.293,18$ & 9,41 \\
\hline
\end{tabular}


MAKALAH ILMIAH

\begin{tabular}{|c|c|c|c|c|c|}
\hline No & Lapangan Usaha & 2012 & 2013 & 2014 & LP \\
\hline \multicolumn{6}{|c|}{ dan Makan Minum } \\
\hline 10 & $\begin{array}{l}\text { Informasi dan } \\
\text { Komunikasi }\end{array}$ & $1.314 .981,83$ & $1.496 .449,83$ & $1.540 .202,45$ & 2,92 \\
\hline 11 & Jasa Keuangan & 1184844,54 & $1.352 .627,27$ & $1.480 .342,34$ & 9,44 \\
\hline 12 & Real Estate & $1.044 .642,05$ & $1.103 .427,99$ & $1.176 .666,07$ & 6,64 \\
\hline 13 & Jasa Perusahaan & $113.427,93$ & $128.187,50$ & $140.671,54$ & 9,74 \\
\hline 14 & $\begin{array}{l}\text { Administrasi } \\
\text { Pemerintahan, } \\
\text { Pertahanan dan } \\
\text { Jaminan Sosial Wajib }\end{array}$ & $3.247 .714,52$ & 3388607,67 & $3.828 .331,51$ & 12,98 \\
\hline 15 & Jasa Pendidikan & $2.533 .177,05$ & $2.824 .985,14$ & $3.219 .902,00$ & 13,98 \\
\hline 16 & $\begin{array}{l}\text { Jasa Kesehatan dan } \\
\text { Kegiatan Sosial }\end{array}$ & $544.734,91$ & $605.007,88$ & $678.375,94$ & 12,13 \\
\hline 17 & Jasa Lainnya & $823.066,02$ & $892.829,95$ & $1.008 .264,41$ & 12,93 \\
\hline \multicolumn{2}{|c|}{$\begin{array}{l}\text { Produk domestik regional } \\
\text { bruto Sulawesi Tenggara }\end{array}$} & $59785.399,06$ & $64.273 .783,78$ & $68.298 .724,30$ & 6,26 \\
\hline \multicolumn{2}{|c|}{$\begin{array}{l}\text { Penduduk pertengahan } \\
\text { tahun }\end{array}$} & 2.345 .465 & 2.396 .713 & 2.448 .081 & \\
\hline \multicolumn{2}{|c|}{$\begin{array}{l}\text { PDRB perkapita ADHB } \\
\text { tahun dasar } 2010 \text { (rupiah) }\end{array}$} & 25.489 .785 & 6.817.472 & 7.898 .883 & \\
\hline
\end{tabular}

Tabel 4.PDRB Atas Dasar Harga Berlaku (Juta Rupiah) Menurut Lapangan Usaha Tahun Dasar 2010, 2012-2014.

\begin{tabular}{rlrrrr}
\hline No & \multicolumn{1}{c}{ Lapangan Usaha } & $\mathbf{2 0 1 2}$ & $\mathbf{2 0 1 3}$ & $\mathbf{2 0 1 4}$ & $\begin{array}{c}\text { Struktur } \\
\text { PDRB }\end{array}$ \\
\hline 1 & $\begin{array}{l}\text { Pertanian, Kehutanan, } \\
\text { dan Perikanan }\end{array}$ & $16.305 .585,70$ & $18.095 .983,92$ & $20.158 .060,05$ & 25,64 \\
\hline 2 & $\begin{array}{l}\text { Pertambangan dan } \\
\text { Penggalian }\end{array}$ & $14.865 .627,39$ & $15.582 .057,71$ & $15.832 .070,66$ & 20,14 \\
\hline 3 & Industri Pengolahan & $3.874 .685,94$ & $4.181 .864,04$ & $4.692 .250,20$ & 5,97 \\
\hline 4 & Pengadaan Listrik, Gas & $24.456,08$ & $25.355,00$ & $27.431,10$ & 0,03 \\
\hline 5 & Pengadaan Air & $122.135,52$ & $138.821,87$ & $163.052,85$ & 0,21 \\
\hline 6 & Konstruksi & $7.401 .424,51$ & $8.329 .077,35$ & $9.690 .353,19$ & 12,33 \\
\hline 7 & $\begin{array}{l}\text { Perdagangan Besar dan } \\
\text { Eceran, dan Reparasi }\end{array}$ & $7.262 .524,25$ & $8.076 .246,80$ & $9.225 .945,13$ & 11,73 \\
\hline Mobil dan Motor & $\begin{array}{l}\text { Transportasi dan } \\
\text { Pergudangan }\end{array}$ & $2.813 .820,12$ & $3.160 .530,12$ & $3.433 .715,89$ & 4,37 \\
\hline 9 & $\begin{array}{l}\text { Penyediaan Akomodasi } \\
\text { dan Makan Minum }\end{array}$ & $364.024,29$ & $404.096,43$ & $454.959,19$ & 0,58 \\
\hline 10 & $\begin{array}{l}\text { Informasi dan } \\
\text { Komunikasi }\end{array}$ & $1.286 .578,22$ & $1.451 .309,48$ & $1.478 .510,56$ & 1,88 \\
\hline 11 & Jasa Keuangan & $1.343 .962,42$ & $1.601 .078,14$ & $1.829 .106,63$ & 2,33 \\
\hline 12 & Real Estate & $1.116 .048,23$ & $1.194 .101,81$ & $1.293 .200,08$ & 1,64 \\
\hline 13 & Jasa Perusahaan & $119.711,83$ & $136.981,16$ & $154.808,82$ & 0,20 \\
\hline 14 & $\begin{array}{l}\text { Administrasi } \\
\text { Pemerintahan, } \\
\text { Pertahanan dan }\end{array}$ & $3.669 .747,34$ & $4.035 .943,63$ & $4.748 .428,74$ & 6,04 \\
\hline & & & & & \\
\hline
\end{tabular}




\begin{tabular}{|c|c|c|c|c|c|}
\hline No & Lapangan Usaha & 2012 & 2013 & 2014 & $\begin{array}{l}\text { Struktur } \\
\text { PDRB }\end{array}$ \\
\hline \multicolumn{6}{|c|}{ Jaminan Sosial Wajib } \\
\hline 15 & Jasa Pendidikan & $2.681 .164,20$ & $3.020 .320,62$ & $3.585 .496,40$ & 4,56 \\
\hline 16 & $\begin{array}{l}\text { Jasa Kesehatan dan } \\
\text { Kegiatan Sosial }\end{array}$ & $589.730,01$ & $662.907,14$ & $760.782,18$ & 0,97 \\
\hline & Jasa Lainnya & $852.758,51$ & $944.613,63$ & $1.092 .217,49$ & 1,39 \\
\hline \multicolumn{2}{|c|}{$\begin{array}{l}\text { Produk domestik regional } \\
\text { bruto }\end{array}$} & $64.693 .984,56$ & $71.041 .288,85$ & $78.620 .389,17$ & 100,00 \\
\hline \multicolumn{2}{|c|}{$\begin{array}{l}\text { Penduduk pertengahan } \\
\text { tahun }\end{array}$} & 2.345 .465 & 2.396 .713 & 2.448 .081 & \\
\hline \multicolumn{2}{|c|}{$\begin{array}{l}\text { PDRB perkapita ADHB } \\
\text { tahun dasar } 2010 \text { (rupiah) }\end{array}$} & 27.582 .584 & 29.641 .133 & 32.115 .109 & \\
\hline
\end{tabular}

Sebagaimana dapat dilihat pada Tabel 5. Selama kurun waktu 2009-2014 angkatan kerja di Provinsi Sulawesi Tenggara meningkat rata-rata setiap tahunnya sebesar 1,71\%. Pada tahun 2009 tenaga kerja di Provinsi Sulawesi Tenggara berjumlah 998.195 jiwa dan meningkat menjadi 1.085.509 jiwa pada tahun 2014 .

Adanya pabrik pengolahan dan pemurnian nikel di Provinsi Sulawesi Tenggara (Tabel 2), memberikan dampak positif dengan adanya penyerapan tenaga kerja mulai tahun 2015 sebanyak 8.104 jiwa dan akan terus meningkat setiap tahunnya sesuai dengan dimulainya operasi pabrik pengolahan dan pemurnian nikel di

wilayah tersebut. Sehingga jumlah tenaga kerja di Provinsi Sulawesi Tenggara pada tahun 2015 berjumlah 1.085 .509 jiwa, bertambah 8.104 jiwa menjadi 1.093 .613 jiwa, dan akan terus meningkat sesuai dengan rencana penyelesaian pabrik pengolahan.

\section{Dampak Terhadap Pendapatan Rumah Tangga (RTK)}

Menghitung PDRB dengan memakai metoda pendapatan, yaitu dengan menjumlahkan seluruh pendapatan sewa (rent) yang diterima oleh faktor produksi pemilik gedung/tanah ditambah dengan penjumlahan seluruh gaji (wage) atau seluruh pendapatan rumah tangga yang diterima oleh faktor produksi tenaga kerja ditambah penjumlahan bunga (interest) yang diterima faktor produksi pemilik modal/aset ditambah penjumlahan seluruh keuntungan (profit) yang diterima pemilik faktor produksi pengusaha dalam suatu negara selama 1 tahun, yang dirumuskan :

$$
\begin{aligned}
& Y=R+W+I+P \\
& Y=\text { pendapatan nasional } \\
& R=\text { pendapatan rent } \\
& W=\text { pendapatan wage } \\
& \mathrm{I}=\text { pendapatan interest } \\
& \mathrm{P}=\text { pendapatan profit. }
\end{aligned}
$$

Oleh sebab itu rencana pembangunan pabrik pengolahan dan pemurnian nikel di Provinsi Sulawesi Tenggara yang berjumlah 20 perusahaan, berdasarkan analisis sebelumnya akan meningkatkan PDRB Provinsi Sulawesi Tenggara (Y).

Berdasarkan analisis sebelumnya, adanya investasi dari pabrik pengolahan dan pemurnian selama tahun 2016-2018 ratarata sebesar Rp. 28.409.941.666.000 per tahun (Rp. 28,41 triliun). Maka PDRB Provinsi Sulawesi Tenggara pada tahun 2016 meningkat menjadi Rp. 68.298.724,30 juta + investasi pabrik (Rp. 28.409.941,66 juta) = Rp. 96.708.665,96 juta (Rp. 96,71 triliun). Tahun 2017 meningkat menjadi Rp. 96,71 triliun + Rp. 28,41 triliun = Rp. 125,12 triliun. Dan pada tahun 2018 setelah seluruh pabrik selesai meningkat menjadi Rp. 125,12 triliun + Rp. 28,41 triliun $=$ Rp. 153,53 triliun. 
Dengan meningkatnya PDRB (Y) dari tahun 2014 sebesar Rp. 68,30 triliun menjadi Rp. 96,71 triliun tahun 2016, dan meningkat kembali pada tahun 2017 menjadi Rp. 125,12 triliun, serta meingkat kembali pada tahun 2018 menjadi Rp. 153,53 triliun. Maka peningkatan PDRB di Provinsi Sulawesi Tenggara yang disebabkan oleh adanya pabrik pengolahan dan pemurnian nikel di wilayah tersebut akan memberikan dampak yang positif dari sisi pendapatan rumah tangga yaitu meningkatkan pendapatan/gaji yang diterima rumah tangga atau pendapatan/gaji yang diterima faktor produksi tenaga kerja. (Tabel 6).

Ada beberapa aspek yang dapat meningkatkan pendapatan rumah tangga atau pendapatan yang diperoleh oleh tenaga kerja akibat meningkatnya Produk Domestik Regional Bruto di Provinsi Sulawesi Tenggara, yang secara langsung adalah meningkatnya UMR (upah minimum regional) yang akan berubah setelah selesainya pabrik pengolahan dan pemurnian nikel di wilayah tersebut. Aspek kedua, yang juga dapat meningkatkan pendapatan rumah tangga/tenaga kerja adalah peningkatan upah karena adanya peningkatan keahlian yang diberikan tenaga kerja, yang biasanya sebagai tenaga kerja buruh yang bekerja pada sektor pertambangan penghasil bahan mentah, menjadi tenaga kerja yang berkeahlian (profesional) yang bekerja pada sektor pertambangan penghasil bahan olahan.

Tabel 5.Penduduk Usia 15 Tahun Keatas Menurut Kegiatan (2009 -2014).

\begin{tabular}{|c|c|c|c|c|c|c|}
\hline KEGIATAN UTAMA & 2009 & 2010 & 2011 & 2012*) & $\left.2013^{* *}\right)$ & $\left.2014^{\star *}\right)$ \\
\hline $\begin{array}{l}\text { Penduduk Usia Kerja } \\
\text { (15 Tahun Ke atas) }\end{array}$ & 1.418 .144 & 1.455 .372 & 1.482 .880 & 1.548 .392 & 1.582 .401 & 1.623 .264 \\
\hline 1. Angkatan Kerja & 998.195 & 1.045 .899 & 1.058 .999 & 1.043 .390 & 1.042 .947 & 1.085 .509 \\
\hline a. Bekerja & 950.876 & 997.678 & 1.026 .548 & 1.000 .570 & 997.231 & 1.037 .419 \\
\hline b. Pengangguran & 47.319 & 48.221 & 32.451 & 42.820 & 45.716 & 48.090 \\
\hline 2. Bukan Angkatan Kerja & 419.949 & 409.473 & 423.881 & 505.002 & 539.454 & 537.755 \\
\hline 3. Tingkat Partisipasi Angkatan Kerja(\%) & 70,39 & 71,86 & 71,42 & 67,39 & 65,91 & 66.87 \\
\hline 4. Tingkat Pengangguran (\%) & 4,74 & 4,61 & 3,06 & 4,10 & 4,38 & 4.43 \\
\hline 5. Pekerja Tidak Penuh & - & - & - & 438.285 & 490.173 & 427.953 \\
\hline Setengah Penganggur & - & - & - & 154.931 & 131.566 & 118.844 \\
\hline Paruh Waktu & - & - & - & 283.354 & 358.607 & 309.109 \\
\hline
\end{tabular}

Sumber: Sulawesi Tenggara dalam Angka, Tahun 2015.

Tabel 6. Produk Domestik Bruto Provinsi Sulawesi Tenggara Atas Dasar Harga Konstan Sebelum dan Sesudah Smelter Berjalan (juta rupiah)

\begin{tabular}{|c|c|c|c|c|c|c|}
\hline PDB & 2012 & 2013 & 2014 & 2016 & 2017 & 2018 \\
\hline $\begin{array}{l}\text { Sebelum ada } \\
\text { smelter }\end{array}$ & $59.785 .399,06$ & $64.273 .783,78$ & $68.298 .742,30$ & & & \\
\hline $\begin{array}{l}\text { Setelah ada } \\
\text { smelter }\end{array}$ & & & & $96.708 .665,96$ & $125.118 .607,62$ & $153.528 .548,00$ \\
\hline
\end{tabular}

Catatan : Smelter mulai berjalan 2006-2018, selama tahun 2016-2018 meningkat setiap tahunnya Rp. 28,41 triliun dari investasi smelter.

$\begin{array}{llr}\text { Peningkatan } & \text { PDRB di Provinsi } \\ \text { Sulawesi } & \text { Tenggara } & \text { dapat }\end{array}$ meningkatkan pendapatan rumah tangga atau pendapatan gaji yang diterima oleh tenaga kerja di wilayah tersebut dapat dirumuskan, sebagai berikut:

Dimana $Y$ (meningkat) $=R$ (meningkat) $+\mathrm{W}$ (meningkat) $+\mathrm{I}$ (meningkat) $+\mathrm{P}$ (meningkat), dengan peningkatan secara fluktuatif dimana salah satu indikator bisa tidak meningkat dan indikator yang lain meningkat lebih besar. $R=$ pendapatan rent/sewa dari pemilik tanah/bangunan, $\mathrm{W}$ =pendapatan wage/gaji dari rumah tangaga/tenaga kerja, $\mathrm{I}=$ pendapatan interest/bunga 
dari pemilik modal/aset, $\mathrm{P}=$ pendapatan profit/laba dari pengusaha/pemilik enterpreneur/ kewirausahaan.

\section{KESIMPULAN}

Atas dasar perhitungan ekonomi di atas, yang menghasilkan PDRB bagi Provinsi Sulawesi Tenggara sebesar Rp. 85,22 triliun dan meningkatkan peluang penambahan tenaga kerja sebanyak 8.100 orang yang secara tidak langsung akan meningkatkan kemampuan daya beli masyarakat daerah tersebut, maka pengembangan industri pabrik pengolahan nikel di Provinsi Sulawesi Tenggara agar segera direalisasikan dan memerlukan upaya dan kerja keras baik dari pemerintah pusat maupun pemerintah Provinsi Sulawesi Tenggara dan pemerintah kabupaten/kota di Provinsi Sulawesi untuk mendukung rencana tersebut sehingga seluruhnya bisa berjalan dan beroperasi sesuai rencana yaitu pada tahun 2018.

\section{UCAPAN TERIMA KASIH}

Pada kesempatan ini penulis mengucapkan terimakasih kepada Kepala Pusat Data Dan Teknologi Informasi Kementerian ESDM yang memberi kepercayaan kepada penulis selaku kontributor laporan, juga kepada Kepala Dinas Pertambangan dan Energi Provinsi Sulawesi Tenggara beserta stafnya, kepada Direktur PT Wijaya Inti Nusantara (PT Jilin Metal), Direktur PT Cahaya Modern Metal Industri (CMMI), Direktur PT Bintang Semelter Indonesia (PT Ifishdeco) yang telah memberikan data dan informasi mengenai industri nikel yang sangat bermanfaat dalam mendukung kajian ini. Semoga kajian ini memberikan manfaat bagi semua pihak yang berkepentingan terhadap industri dan pertambangan nikeldi Provinsi Sulawesi Tenggara, khususnya industri pertambangan nikel di Indonesia.

\section{DAFTAR PUSTAKA}

Amir, M.S, 2004. Seluk beluk dan teknik perdagangan luar negeri, Jakarta. 389 halaman.

Anonim, 2015. Daftar Rencana Pembangunan Pabrik Pengolahan dan Pemurnian di Provinsi Sulawesi Tenggara. Kendari. Dinas Pertambangan dan Energi Provinsi Sulawesi Tenggara.

Anonim, 2011. Masterplan Percepatan dan Perluasan Pembangunan Ekonomi Indonesia, 2011-2025. Jakarta. Kantor Kementerian Koordinator Bidang Perekonomian.

Anonim, 2015. Sulawesi Tenggara Dalam Angka, 2014. Kendari. Badan Pusat Statistik Provinsi Sulawesi Tenggara. 510 halaman.

Bank Indonesia. (2013). Laporan Bank Indonesia ke Dewan Perwakilan Rakyat Indonesia Kuartal II Tahun 2013. Bank Indonesia.

Anonim, 2015. Statistik potensi dan neraca sumber daya mineral, dan batubara. Jakarta. Direktorat Jenderal Mineral dan Batubara. 97 halaman.

Direktorat Jenderal Mineral dan Batubara, 2015. Indonesia mineral, coal, geothermal and groundwater statistics, 2014. Jakarta. 129 halaman.

Dinas Pertambangan Propinsi Sulawesi Tenggara, 2015. Pertambangan Propinsi Sulawesi Tenggara. Kendari. 127 halaman.

Haryadi, H. 2010. Perkembangan dan Prospek Bahan Galian Non-Logam Indonesia. Jurnal Teknologi Mineral dan Batubara, Vol. 6 No.1 Januari 2010. Bandung, hal 45-62.

Kementerian Perdagangan, 2013. Perdagangan ekspor dan impor Indonesia, Pusat Data dan Informasi Kementerian Perdagangan, Jakarta. 203 halaman.

Kementerian Perindustrian, 2013. Sambutan Menteri Perindustrian Pada Acara Forum Eksporlndustri Manufaktur. Jakarta 2013. 


\section{MAKALAH ILMIAH}

Kementerian Perindustrian, 2015. Laporan Tahunan

Kementerian

Perindustrian, 2014.Jakarta, 2015.

Kementerian Keuangan. 2015. Nota

Keuangan Dan Rancangan

Anggaran Pendapatan Belanja Negara Tahun Anggaran 2014.

Permana, D. 2010. Pengkajian Peraturan Daerah (Perda) di Bidang Pertambangan Umum (Mineral dan Batubara). Jurnal Teknologi Mineral dan Batubara, Vol. 6 No.3 Juli 2010. Bandung, hal 108-105.

Permana, D. 2010. Dampak Penerapan Undang-Undang No. 4 Tahun 2009 Tentang Pengembangan Usaha Pertambangan Mineral dan Batubara. Jurnal Teknologi Mineral dan Batubara, Vol. 6 No.4 Oktober 2010. Bandung, hal 165-173.

Pusat Penelitian dan Pengembangan Teknologi Mineral, 2010. Kamus Pertambangan. Bandung. 862 Halaman.

Pusat Sumber Daya Geologi, 2015. Mineral Potential Map, Sulawesi, Flores, and West Timor. Bandung 78 halaman.

Pusat Data dan Teknologi Informasi ESDM, 2015. Dampak
Pembangunan Smelter Di Kawasan Ekonomi Khusus Provinsi Sulawesi Tenggara. Jakarta 102 halaman.

Pujoalwanto, B. 2014. Perekonomian Indonesia, Tinjauan Historis, Teoritis dan Empiris.Jakarta : Graha IImu.

Provinsi Sulawesi Tenggara, 2013. "Letak Geografis Propinsi Sulawesi Tenggara,

2012".www.sultraprov.go.id/Sulawe si_Tenggara_09/index.php.

Diunduh 11 Januari 2015, jam 10.25 .

Ratya, A. dan Michael, R., 2009. Bisnis dan perdagangan internasional, Jakarta. 196 halaman.

Sugiarto dan Herlambang T., 2006. Ekonomi Makro Teori, Analisis dan Kebijakan Dalam Bisnis Manajemen dan Keuangan. Gramedia, Jakarta. 296 halaman.

Tulus, T., dan Simon, K., 2004. Perdagangan internasional dan neraca pembayaran, teori dan temuan empiris. LP3ES Jakarta. 217 halaman.

\begin{tabular}{|ll|}
\hline Diterima & $: 1$ Maret 2016 \\
Direvisi & $: 14$ April 2016 \\
Disetujui & $: 9$ Mei 2016 \\
\hline
\end{tabular}

